\title{
EXPERIMENTAL RESPONSE TO DENSITY LEVELS IN THE DEVELOPMENT OF TADPOLES AND FROGLETS OF Boana pulchella (ANURA: HYLIDAE)
}

\author{
Raúl Maneyro ${ }^{1 *} \&$ Gabriel Francescoli² \\ ${ }^{1}$ Laboratorio de Sistemática e Historia Natural de Vertebrados, Facultad de Ciencias, Universidad de la \\ República, Iguá 4225, 11400 Montevideo, Uruguay. E-mail: rmaneyro@ fcien.edu.uy. \\ 2 Sección Etología, Facultad de Ciencias, Universidad de la República, Iguá 4225, 11400 Montevideo, \\ Uruguay. E-mail: gabo@fcien.edu.uy. \\ * Corresponding author: rmaneyro@fcien.edu.uy
}

\begin{abstract}
.
Density has been proposed as a factor that could determinate larval growth in anurans. We studied such effects on Boana pulchella. After hatching, we reared the tadpoles during 90 days and 93 tadpoles with similar size and developmental stages were chosen. We placed them in $800 \mathrm{~cm}^{3}$ cans with declorified water at five densities (1, 2, 4, 8 and 16 individuals/can) with three replicates for each treatment. In all the cans the feeding was ad libitum, and they were maintained until the end of the Gosner's developmental stage 42. Each time that a tadpole was extracted, a proportional water volume was too, in order to maintain constant densities. We found significant differences among treatments for froglets' length, mandibular width and mass, while these differences were not significant for metamorphic time. Since the tadpoles were feeding ad libitum an explanation by competitive trophic interactions for that differences could be discarded. These differences could be evidence that density has significant effects.
\end{abstract}

KEYWORDS: Density, metamorphosis, tadpoles, Boana pulchella.

\section{RESUMEN.}

Respuesta experimental a niveles de densidad en el desarrollo de larvas y metaformorfos de Boana pulchella (Anura: Hylidae).

La densidad ha sido propuesta como un factor que puede determinar el crecimiento larvario en los anuros. Se estudió estos efectos en Boana pulchella. Luego de la eclosión, se criaron a las larvas durante 90 días y se seleccionaron 93 renacuajos con tamaños y estados de desarrollo similares. Luego se colocaron en recipientes de $800 \mathrm{~cm}^{3}$ con agua declorada en cinco densidades (1, 2, 4, 8 y 16 individuos/ recipiente) con tres réplicas por cada tratamiento. En todos los recipientes la alimentación fue ad libitum, y las larvas fueron mantenidas hasta el final del estado de desarrollo 42 de Gosner. Cada vez que una larva era extraída, un volumen proporcional de agua era extraído también, para mantener constante las densidades. Se encontraron diferencias significativas entre tratamientos para las variables: tamaño de los metamorfos, ancho mandibular y masa, al tiempo que las diferencias en el tiempo de metamorfosis no fueron significativas. Debido a que las larvas fueron alimentadas ad libitum se descarta que las diferencias se relacionen con interacciones tróficas competitivas. Estas diferencias podrían evidenciar que la densidad tiene efectos significativos.

PALABRAS CLAVE: Densidad, metamorfosis, renacuajos, Boana pulchella.

\section{INTRODUCTION}

Phenotypic plasticity could be defined as the variation in one or more characters, in response to variations in environmental conditions (Via \& Lande, 1985; Nespolo, 2000; Whitman \& Agrawal, 2009). This phenomenon has been studied in many organisms, because it is a practical tool to elucidate potential ecological interactions, like inter or intraspecific competition and predation. Tadpoles (anuran larvae), are one of the most widespread model organisms for the study of this ecological interactions (Brockelman, 1969; Alford, 1999; Relyea 2001).

Tadpoles respond to variation in resources, and many factors have been reported as determinant of amphibian's development (Leips \& Travis, 1994; Newman, 1994; Touchon et al., 2013; Fan et al., 2014). Among the biotic ones, the relationship between predator presence and performance of tadpoles and froglets has been well studied (Werner \& McPeek, 1994; Relyea, 2001). Additionally, changes in food quantity (Wilbur, 1977a; Steinwascher, 1979) and presence of competitors (Griffiths et al., 1993) have been signaled as other relevant causes for changes in tadpoles performances. Finally, density levels are another known biotic factor influencing amphibian survivorship and development (i.e.: Brockelman, 1969; Denver et al., 1998; Laufer \& Maneyro, 2008). In fact, intraspecific competition caused by density in exotrophic anuran larvae negatively affects size and performance of tadpoles (DeBenedictis, 1974; Dash \& Hota, 1980; Semlitsch \& Caldwell, 1982). However, density levels had also been signed as a factor that could positively influence the development of anuran larvae too, mainly through facilitated access to food (Eterovick, 2000). 
The duration of the metamorphic period affects froglets' size (Wilbur \& Collins, 1973; Werner, 1986), and consequently their post-metamorphic performance (Clarke, 1974; Pough \& Kamel, 1984; Werner, 1986; Smith, 1987). Indeed, many trade-offs could be identified, mainly between remaining in the aquatic habitat and size at metamorphosis. This fact could be obvious for amphibians inhabiting variable environments, where the duration of an ephemeral pond is the main determinant of metamorphic timing (Denver, 1997; Denver et al., 1998) and some species accelerate metamorphosis as a response to habitat desiccation (Newman, 1988; 1989). However, in species that live in permanent ponds those trade-offs are less evident.

The hylid frog, Boana pulchella (Duméril \& Bibron, 1841 ) is one of the most common species among Uruguayan anurans (Maneyro \& Carreira, 2012). This species has reproductive activity along the whole year (Langone, 1994) but some populations use to show high reproductive activity during cold seasons (Ximenez \& Tozetti, 2015). Males call from sites with dense vegetation (Santos et al., 2016) and the eggs are laid in a gelatinous mass, attached to aquatic vegetation, mainly in lentic water bodies (Maneyro \& Carreira, 2012). The tadpoles are exotrophic thus having a nonspecialized behavior that can be described as a Type I reproductive mode (sensu Duellman \& Trueb, 1994). Previous experimental works on this species have demonstrated that density and food levels affect tadpoles' growth (i.e. Kehr, 1989).

The aim of this work is to assess the variation in size (tadpoles and froglets) and duration of metamorphosis of this frog as a response to different density levels.

\section{METHODS}

\section{Experimental design}

A clutch of Boana pulchella was collected (27 April 2004) in Coronilla (Rocha, Uruguay). After hatching, the larvae were maintained in an aquarium for three months (to avoid mortality during the experiment), and they fed on a mix of boiled Lactuca sp. and Beta-fish commercial food. After this period, 93 similar-size tadpoles at the 26th developmental stage (Gosner, 1960) were randomly selected and the experiment begun on July $25^{\text {th }}, 2004$.

The tadpoles were reared in the laboratory in one-liter containers with $800 \mathrm{cc}$ of declorified water each one. The experimental design consisted in five density levels (1, 2, 4, 8 and 16 tadpoles by each 800 cc container) with three replicates each. The containers were randomly arranged to avoid microenvironmental variation to affect treatments. Food consisted in a mix of boiled Lactuca sp., boiled spinach and Beta-fish commercial food and was provided ad libitum. The water was changed three to four times a week.

When a tadpole reached the $42^{\text {nd }}$ developmental stage (Gosner, 1960), it was extracted from the container and a proportional water volume was extracted too in order to maintain a constant density in each container.

\section{Data acquisition}

Each tadpole was measured three times during the experiment, with a digital caliper (accuracy 0,05 $\mathrm{mm}$ ). The measurements taken were (following McDiarmid \& Altig, 1999): body length (BL), tail length (TAL), maximum width (MW) and maximum height (MTH). First measures were taken thirty days after the beginning of the experiment (August 25 th, 2004$)$. The last two were on September $2^{\text {nd }}, 2004$ and September $18^{\text {th }}, 2004$.

At metamorphic climax (stage $42^{\text {nd }}$ ), the froglets were sacrificed and weighed $(\mathrm{M})$ with a Pesola dynamometer (accurate 0,1 g). Two measures were taken with a digital caliper (accuracy 0,05 mm): SnoutVent length (SVL) and Mandibular width (MdW). Additionally, the number of days from the beginning of the experiment to metamorphic climax $(\mathrm{T})$ was recorded.

\section{Statistical Analysis}

An index (IT) was developed to analyze the performance of tadpoles related to time. Its expression is: IT $=\left[\left(B L^{*} M W^{\star} M T H\right)^{1 / 3}+\left(T A L^{*} M T H\right)^{1 / 2}\right] / D Y$, where $\mathrm{BL}, \mathrm{MW}, \mathrm{MTH}$ and $\mathrm{TAL}$ corresponds to the morphometric variables explained above, while DY is the number of days from hatching (so its results could be expressed as $\mathrm{mm} /$ day). After verification of normality and homoscedasticity in IT, differences among density treatments were tested using ANOVA.

The effects of density on tadpoles' growth along time were tested using MANOVA. In this case the independent variables were density (D) and date (DT), while the dependent variables were: $\mathrm{BL}, \mathrm{TAL}, \mathrm{MW}$ and MTH. A $\log _{10}$-transformation was used when a variable had not homogeneous variance (heteroscedasticity). Differences in tadpole size among density treatments were tested using ANOVA for each date.

A second index was developed for the froglets (IF). Its expression is IF= M/T, where $M$ is the mass (grams) at the end of the experiment, and $T$ is the number of days from hatching to end of the experiment (then its results could be expressed as gr/day).

The effects of density on size of froglets, IF and metamorphic timing (number of days until metamorphic climax) were analyzed using ANOVA. For the variable "number of days" (T) a $\log _{10}$-transformation of $\mathrm{T}$ was necessary to obtain homogeneity of variances. Additionally, a MANCOVA was performed in order to include possible effects of metamorphic timing (covariance) in the variation of froglets size among treatments (density). 


\section{RESULTS}

\section{Effects of density and time on tadpoles size}

An ANOVA performed on IT showed significant differences ( $F=13.33, g l=4, p<0.001)$. The size of Boana pulchella tadpoles analyzed by MANOVA and measured as body length, tail length, maximum width, and maximum height varied among treatments (density) and among dates (Table 1). There was a decrease for each of the four morphometric variables as a response to an increase in density, and an increase among the three dates when the tadpoles were measured (Figure 1). Those differences in morphometric variables, analyzed by ANOVA, were significant among treatments too (Table 2).

\section{Effects of density and timing on froglets size}

The effects of density were significant for froglets size (measured as mass, snout-vent length and mandibular width) and not significant for the duration of the metamorphosis (Table 3). When the effect of density on froglets size was analyzed using the duration of the metamorphosis as covariable, significant effects were detected in each morphometric variable (Table
Table 1. Summary of MANOVA at five levels of density (D) and three dates (DT) on tadpoles size of Boana pulchella (dependent variables: body length, tail length, maximum width, maximum height). Significant effects are marked with *

\begin{tabular}{lccccc} 
& Wilks' Lambda & Rao's R & df D & dfDT & p \\
\hline D * & .684436 & 6.59050 & 16 & 798 & .000000 \\
DT * & .682681 & 13.72170 & 8 & 522 & .000000 \\
D + DT & .885780 & 1.00736 & 32 & 964 & .456907
\end{tabular}

4). Additionally, the slope in the scatter plots of size (mass, snout-vent length and mandibular width) vs. duration of metamorphosis ( $\log _{10}$ transformed), decreased as the density increased (Figure 2). Additionally, an ANOVA performed on the IT showed significant differences too $(F=11.38, g l=4, p<$ 0.001).

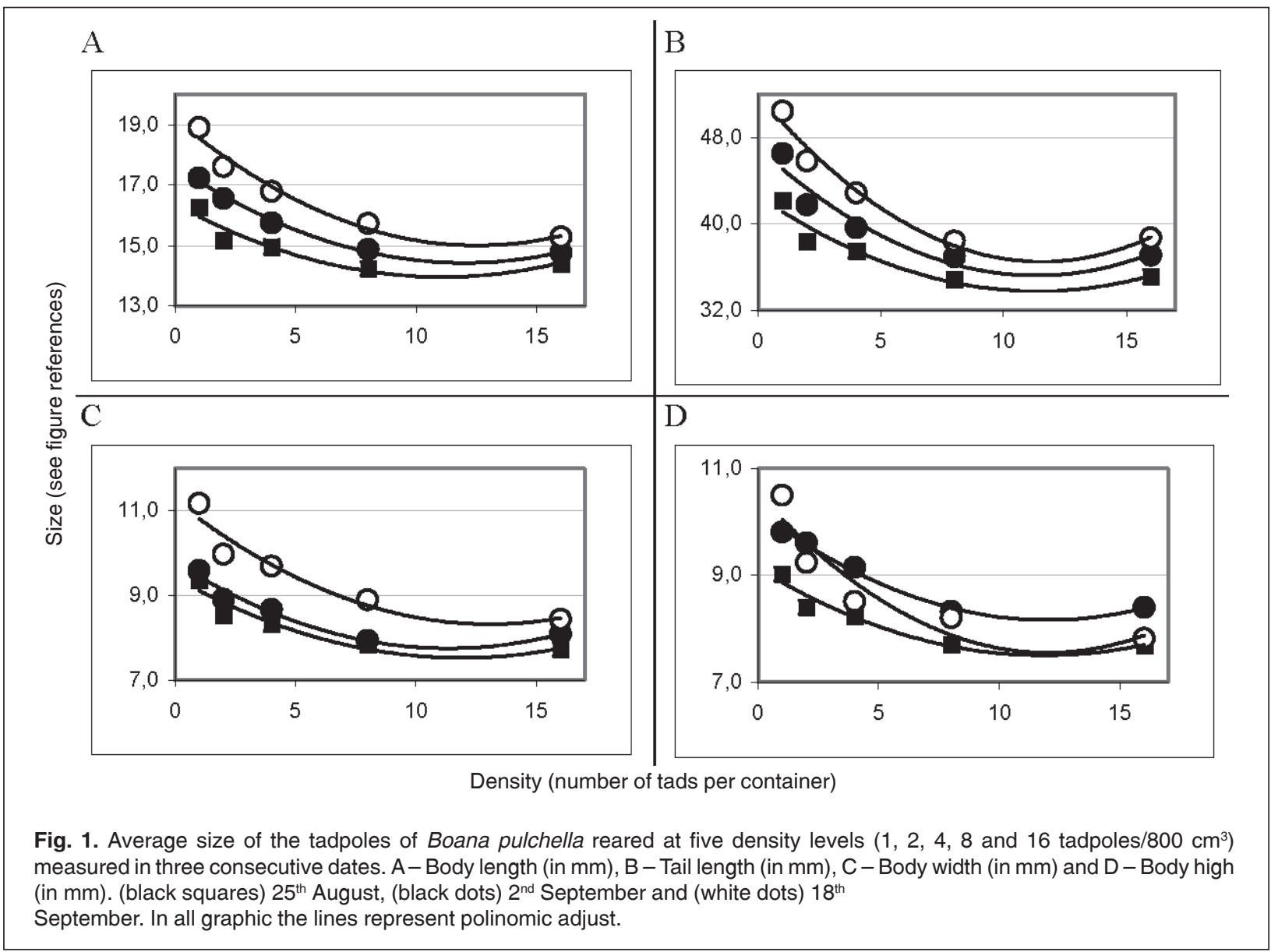

Bol. Soc. Zool. Uruguay (2ª época). 2019. Vol. 28 (2): 79-86 ISSN: 0255-4402 


\section{DISCUSSION}

\section{Effects of density and time on tadpoles size}

Several works have highlighted that first developmental stages are critical to determinate the fitness of individuals during metamorphosis and also at its end (Leips \& Travis, 1994; Newman, 1994). In this experiment, there was a response to differential density levels although tadpoles were maintained in the same conditions during three months (until the 26th developmental stage) and after that similar size individuals were randomly selected. As would be expected, during the experiment the tadpole sizes increased along time. Size (measured as body length, maximum width, maximum height and tail length) differed significantly among dates and treatments (Table 1 ), as did growth rate (based on IT). Additionally, in Figure 1 those differences in the morphometric variables between treatments can be observed. Tadpoles reared at low densities were bigger than those reared at higher densities for all morphometric variables. When these variables were analyzed independently, they showed significant differences among treatments too (Table 2).

In previous work, differences in growth rate in tadpoles were interpreted as a response to competition for resources (Brockelman, 1969; Wilbur, 1977b). In laboratory conditions, at low food levels, body size increased with food supply, while as the food supply increases on critical levels, growth could decrease. This was interpreted as a consequence of water pollution, because this phenomenon was not observed in nature (Wilbur, 1977b). Additionally, at low food levels, exploitative mechanisms are less important, and interference (chemical, mechanical) seems to have the main effect on feeding ability in tadpoles reared under experimental conditions (Steinwascher, 1978). Density is one of the determinants of tadpoles' development, at least in non-aggregative species; since it was demonstrate that food level is more important than density for larval development in Leptodactylus latrans (Laufer \& Maneyro, 2008).

Since in the present work tadpoles were fed ad libitum and the water was frequently changed, direct competition for resources or due to water pollution not occurred. So, differences in size among density treatments could be attributable to competition by interference (probably mechanical), as was proposed in previous works (Kher, 1989), however differences in oxygen level among treatments can not be discarded.

\section{Effects of density and timing on froglets size}

After the metamorphic climax, the effects of density were relevant too. Effects in froglets sizes as a response to density levels were significant, but the duration of the metamorphosis was not (Table 3). However, significant differences in size were found among treatments when duration of the metamorphosis was used as a covariable (Table 4). This observation can be complemented by differences among slopes of each treatment for the growth rate (morphometric variables vs. duration of metamorphosis), as can be observed in Figure 2. Moreover, the growth rate for

Table 2. Effects of five density levels on size of tadpoles of Boana pulchella at three dates (ANOVA results). BL - Body length, $T L-T a i l$ length, MW - Maximum width, MH - Maximum height. Number of days since the beginning of the experiment in brackets. Significant effects are marked with *.

\begin{tabular}{ccccccc} 
DATE & Variable & SS & df & MS & F & P \\
\hline \multirow{2}{*}{25 august (30) } & $\mathrm{BL}^{*}$ & 0.164609 & 4 & 0.041152 & 3.133762 & 0.018503 \\
& $\mathrm{TL}^{*}$ & 2.413034 & 4 & 0.603259 & 6.307502 & 0.000165 \\
& $\mathrm{MW}^{*}$ & 0.124361 & 4 & 0.031090 & 4.784805 & 0.001538 \\
& $\mathrm{MH}^{*}$ & 0.095402 & 4 & 0.023851 & 2.692078 & 0.036081 \\
02 setpember (38) & $\mathrm{BL}^{*}$ & 0.380604 & 4 & 0.095151 & 6.713191 & 0.000092 \\
& $\mathrm{TL}^{*}$ & 4.021413 & 4 & 1.005353 & 8.329538 & 0.000010 \\
& $\mathrm{MW}^{*}$ & 0.136793 & 4 & 0.034198 & 5.746085 & 0.000372 \\
& $\mathrm{MH}^{*}$ & 0.179468 & 4 & 0.044867 & 4.031951 & 0.004756 \\
& $\mathrm{BL}^{*}$ & 0.442474 & 3 & 0.147491 & 5.992997 & 0.000930 \\
& $\mathrm{TL}^{*}$ & 4.374006 & 3 & 1.458002 & 8.671316 & 0.000043 \\
& $\mathrm{MW}^{*}$ & 0.242352 & 3 & 0.080784 & 8.847148 & 0.000036 \\
& $\mathrm{MH}^{*}$ & 0.138158 & 3 & 0.046053 & 6.233944 & 0.000701 \\
\hline
\end{tabular}

$\S$ The lowest density treatment was not considered for this date. 

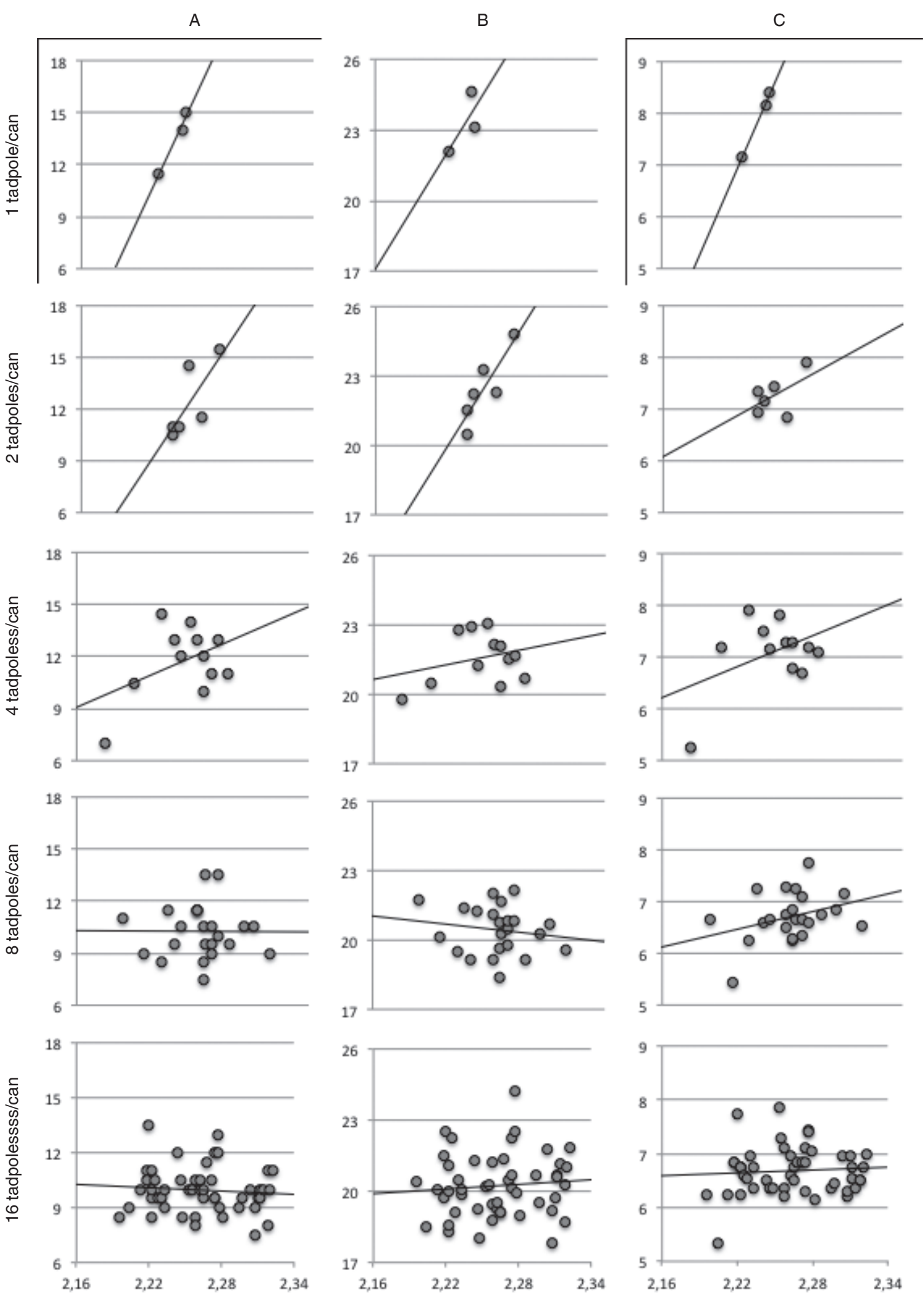

$\log _{10}(\mathrm{n}$ of days) (en la $\mathrm{x}$ mir abajo)

Fig. 2. Lineal regressions between metamorphic duration ( $\log _{10}$ transformed) and mass (in grams) (A), snout-vent length (as SVL, in $\mathrm{mm}$ ) (B) and mandibular width (as MW, in $\mathrm{mm}$ ) (C) for Boana pulchella froglets reared at five density levels $(1,2,4,8$, and 16 tadpoles per can). 
Table 3. Summary of the ANOVA at five levels of density on Boana pulchella froglets size and timing. M - mass, SVL - Snoutvent length, MdW - Mandibular width, log T - logaritmic transformation of time of metamorphosis. Significant effects are marked with *

\begin{tabular}{cccccc} 
Variable & SS & df & MS & $\mathbf{F}$ & $\mathbf{p}$ \\
\hline M * $^{*}$ & 81.97967 & 4 & 20.49492 & 9.145660 & .000003 \\
SVL * $^{*} 59.69226$ & 4 & 14.92306 & 9.844669 & .000001 \\
MdW * $^{*} 6.87056$ & 4 & 1.71764 & 7.253699 & .000043 \\
$\log T$ & .00655 & 4 & 0.00164 & 1.674122 & .163134 \\
\hline
\end{tabular}

froglets (measured as IF) exhibited significant differences among density treatments.

Metamorphosis has been signaled as influenced by a trade off between time and size (Duellman \& Trueb, 1994; Stebbins \& Cohen, 1997). Positive effects of intraspecific interactions were reported in laboratory studies. Among other consequences, intraspecific interactions may increase metamorphic duration (Breden \& Kelly, 1982) and may produce bigger froglets (Wilbur, 1977a). Additionally, these interactions may decrease metamorphic synchrony (Breden \& Kelly, 1982). The latter is relevant for tadpoles with aggregative behavior, since synchronic metamorphosis has been suggested as an antipredatory mechanism (d'Heursel \& Haddad, 2002; Mares, 1972). In the present work, the size of the froglets seemed to be determined by the duration of metamorphosis at lower densities, but for density itself at higher ones (Figure 2). Boana pulchella has not aggregative behavior, so differences in the slopes in Figure 2, could be interpreted as a response to the above-mentioned trade-off. This means that in optimal conditions (low density and high food levels) metamorphic time is expected to be greater and, consequently, froglets would be bigger. Conversely, at high densities the possible facilitation of access to food (positive effect) could not compensate the negative effects of interference, and at similar metamorphic time, the froglets are smaller.

Even if tadpoles were provided with food ad libitum it is possible to think about some other advantageous reasons of increasing in size. One of those advantages is that bigger (healthier, stronger) tadpoles and froglets could avoid predation more easily than others (Crump, 1984). Additionally, bigger froglets can be less susceptible to pathogens (like Batrachochytrium dendrobatidis) since they maintain homeostasis easier than smaller individuals (Wu et al., 2018). Other advantage of the increased size is the possibility of maintaining a higher body mass in
Table 4. Summary of MANCOVA at five levels of density (treatments) on Boana pulchella froglets size. Co-variable = Metamorphosis time (log transformed). M - mass, SVL - Snoutvent length, MdW - Mandibular width. Wilks' Lambda = .635296, Rao's $R=3.509943, d f=12,225, p=.000089$. Significant effects are marked with *

\begin{tabular}{cccc} 
Var. & MS & $\mathbf{F}(\mathbf{d f}=\mathbf{4 , 8 7})$ & $\mathbf{p}$ \\
\hline $\mathrm{M}^{*}$ & 19.96276 & 8.832767 & .000005 \\
$\mathrm{SVL}^{*}$ & 14.96437 & 9.841393 & .000001 \\
$\mathrm{MdW}$ * & 1.90705 & 8.295430 & .000010 \\
\hline
\end{tabular}

the next stage of development, thus enhancing the competing abilities of bigger individuals, as was demonstrated for Lithobates sphenocephalus (Steinwascher, 1978). Another advantage could be, in the same vein, that being bigger allows fully developed animals to capture and consume bigger prey, a proved fact in Boana pulchella (Maneyro \& da Rosa, 2004).

The effect of predation could be considered as one of the main possibilities influencing the results here obtained on an evolutionary scale. However, that influence should be tested in order to assess its importance. If predation pressure is not found to be the main reason of the increase in size when other conditions are the same, we could be facing a scenario showing some kind of "anticipative" behavior by the tadpoles. This behavior would have an advantage only after metamorphosis and when the animals change their living environment and way of life.

Finally, the date when the froglets finished their metamorphosis in the experiment (November) is coincident with that observed in nature. These observations where made in two wild Uruguayan populations: one in the South (Balneario Solís, departamento de Maldonado) where froglets arrived to stage $42^{\text {nd }}$ in December, and the other in the North (Parque Gran Bretaña, departamento de Rivera), where they did it in November (Maneyro Obs. Pers.). However, during these field observations the froglets seemed to be bigger than the biggest tadpole in the experiments here described. This fact suggests that in spite of some factors (like food availability) were compensated during the experiment, other potential factors could be responsible for these differences (size in nature bigger than size in low density experiments). So, it could be interesting to search which are these effects and how they act on individuals in wild populations inhabiting natural environments. 


\section{ACKNOWLEDGMENTS}

The authors are grateful to Mariana Beheregaray for valuable help in the laboratory works and to Ismael Etchevertz for supplying biological matherial. We also thank to Arturo Kher and Gabriel Laufer for sent us comments and pertinent bibliography. The Comisión Sectorial de Investigación Científica (CSIC - Uruguay) provided partial economical support.

\section{REFERENCES}

Alford R.A. 1999. Ecology: Resource use, competition, and predation. In: Altig R. \& R.W. McDiarmid (Eds). Tadpoles: the biology of anuran larvae, pp. 240-278. The University of Chicago Press, Chicago \& London.

Breden F. \& C.H. Kelly. 1982. The effect of conspecific interactions on metamorphosis in Bufo americanus. Ecology, 63: 1682-1689.

Brockelman W.Y. 1969. An analysis of density effects and predation in Bufo americanus tadpoles. Ecology, 50: 632-644.

Clarke R.D. 1974. Postmetamorphic growth rates in a natural population of the Fowler's toad (Bufo woodhousei fowleri). Canadian Journal of Zoology, 52: 1458-1498.

Crump M.L. 1984. Ontogenic changes in vulnarability to predation in tadpoles of Hyla pseudopuma. Herpetologica, 40: 265-271.

D'Heursel A. \& C.F.B. Haddad. 2002. Schooling and swimming behaviors of Hyla semilineata tadpoles (Anura, Hylidae). Iheringia (Série Zoologia), 92: 99-104.

Dash M. \& A.K. Hota 1980. Density effects on the survival, growth rate, and metamorphosis of Rana tigrina tadpoles. Ecology, 61: 1025-1028.

DeBenedictis P.A. 1974. Interspecific competition between tadpoles of Rana pipiens and Rana sylvatica: an experimental field study. Ecological Monographs, 44: 129-151.

Denver R.J. 1997. Proximate mechanisms of phenotypic plasticity in amphibian metamorphosis. American Zoologist, 37: 172184.

Denver R.J., Mirhadi N. \& M. Philips. 1998. Adaptive plasticity in amphibian metamorphosis: response of Scaphiopus hammondii tadpoles to habitat dessication. Ecology, 79: 1859-1872.

Duellman W. \& L. Trueb. 1994. Biology of Amphibians. Maryland. The Johns Hopkins University Press. $670 \mathrm{pp}$.

Eterovick P.C. 2000. Effects of aggregation on feeding of Bufo crucifer tadpoles (Anura, Bufonidae). Copeia, 2000: 210-215.

Fan X.L., Lin Z.H. \& J. Wei. 2014. Effects of hydroperiod duration on developmental plasticity in tiger frog
(Hoplobatrachus chinensis) tadpoles. Zoological Research, 35(2): 124-131.

Gosner K.L. 1960. A simplified table for staging anuran embryos and larvae with notes on identification. Herpetologica, 16: 183-190.

Griffiths R.A., Denton J. \& A.L.C. Wong. 1993. The effect of food level on competition in tapoles: interference mediated by protothecan algae? Journal of Animal Ecology, 62: 274-279.

Kehr A.I. 1989. Factores dependientes de la densidad y su influencia sobre el crecimiento individual de los estados larvales de Hyla pulchella pulchella (Amphibia: Anura). Limnobios, 2: 757 761.

Langone J. 1994. Ranas y Sapos del Uruguay (Reconocimiento y aspectos biológicos). Intendencia Municipal de Montevideo. Serie Divulgación, 5: 1-123.

Laufer G. \& R. Maneyro. 2008. Experimental test of intraspecific competition mechanisms among tadpoles of Leptodactylus ocellatus (Anura: Leptodactylidae). Zoological Science, 25(3): 286-290.

Leips J. \& J. Travis. 1994. Metamorphic responses to changing food levels in two species of Hylid frogs. Ecology, 75: 1345-1356.

Maneyro R. \& S. Carreira, S. 2012. Guía de anfibios del Uruguay. Montevideo. Ediciones de la Fuga. $207 \mathrm{pp}$.

Maneyro R. \& I. da Rosa. 2004. Temporal and spatial changes in the diet of Hyla pulchella Duméril and Bibron, 1841 (Anura: Hylidae) in Southern Uruguay. Phyllomedusa, 3: 101-114.

Mares M.A. 1972. Notes on Bufo marinus tadpole aggregations. The Texas Journal of Science, 23: 433-435.

McDiarmid W. \& R. Altig. 1999. Research: Material mand Techniques. En: Altig R. \& R.W. McDiarmid (Eds.). Tadpoles: the biology of anuran larvae, pp. 7-23. The University of Chicago Press, Chicago \& London.

Nespolo R.F. 2000. Desempeño fisiológico, estacionalidad y plasticidad fenotípica en pequeños mamíferos: microevolución de la capacidad de cambio en rasgos termorregulatorios. Revista Chilena de Historia Natural, 73: 553-563.

Newman R.A. 1988. Adaptive plasticity in development of Scaphiopus couchii tadpoles in desert ponds. Evolution, 42: 774-783.

Newman R.A. 1989. Developmental plasticity of Scaphiopus couchiitadpoles in an unpredictable environment. Ecology, 70: 1775-1787.

Newman R.A. 1994. Effects of changing density and food level on metamorphosis of a desert amphibian, Scaphiopus couchii. Ecology, 75: 1085-1096.

Pough F.H. \& S. Kamel. 1984. Post-metamorphic 
change in activity metabolism of anurans in relation to life history. Oecologia, 65: 138-144.

Relyea R.A. 2001. The lasting effects of adaptive plasticity: predator-induced tadpoles become long-legged frogs. Ecology, 82: 1947-1955.

Santos N.L.P.S., Colombo, P., Avila, F.R. \& A.M. Tozetti, 2016. Calling site selection by the South American Tree-Frog Hypsiboas pulchellus (Anura, Hylidae) in subtropical wetlands. South American Journal of Herpetology, 11: 149-156.

Semlitsch R.D. \& J.P. Caldwell. 1982. Effects of density on growth, metamorphosis and survivorship in tadpoles of Scaphiopus holbrooki. Ecology, 63: 905-911.

Smith D.C. 1987. Adult recruitment in chorus frogs: effects of size and date at metamorphosis. Ecology, 68: 344-350.

Stebbins R.C. \& N.W. Cohen. 1997. A natural history of amphibians. Princeton University Press. New Jersey. 316 pp.

Steinwascher K. 1978. Interference and exploitation competition among tadpoles of Rana utricularia. Ecology, 59: 1039-1046.

Steinwascher K. 1979. Competitive interactions among tadpoles: responses to resource level. Ecology, 60: 1172-1183.

Touchon J.C., McCoy M.W., Vonesh J.R. \& K.M. Warkentin. 2013. Effects of plastic hatching timing carry over through metamorphosis in redeyed treefrogs. Ecology, 94:850-860

Via S. \& R. Lande. 1985. Genotype-environment interaction and the evolution of phenotypic plasticity. Evolution, 39: 505-522.

Werner E.E. 1986. Amphibian metamorphosis: growth rate, predation risk, and the optimal size at transformation. American Naturalist, 128: 319341.

Werner E. E. \& M. A. McPeek. 1994. Direct and indirect effects of predators on two anuran species along an environmental gradient. Ecology, 75: 13681382.

Whitman D.W. \& A.A. Agrawal. 2009. What is phenotypic plasticity and why is it important? In: D.W. Whitman y T.N. Ananthakrishnan (Eds.). Phenotypic plasticity of insects: mechanisms and consequences, pp. 1-63. Scientific Publishers, Enfield.

Wilbur H.M. 1977a. Density-dependent aspects of growth and metamorphosis in Bufo americanus. Ecology, 58: 196-200.

Wilbur H.M. 1977b. Interactions of food level and population density in Rana sylvatica. Ecology, 58: 206-209.

Wilbur H.M. \& J.P. Collins. 1973. Ecological aspects of amphibian metamorphosis. Science, 182: 130510314.

Wu, N.C.; Cramp, R.L. \& C.E. Franklin. 2018. Body size influences energetic and osmoregulatory costs in frogs infected with Batrachochytrium dendrobatidis. Scientific Reports, 3739: 1-11.

Ximenez S.S. \& A.M. Tozetti. 2015. Seasonality in anuran activity and calling season in a Brazilian subtemperate wetland. Zoological Studies, 54: 47. 